\title{
Street Vendors Hypergrowth: Consequence of Uncontrolled Urbanization In Semarang City
}

Komunitas: International Journal of Indonesian Society and Culture 9(1) (2017): 81-91

DOI:10.15294/komunitas.v9i1.8497 (C) 2017 Semarang State University, Indonesia p-ISSN 2086 - 5465 | e-ISSN 2460-7320 http://journal.unnes.ac.id/nju/index.php/komunitas

UNNDS JOURNALS

\author{
Sariffuddin ${ }^{1}$, Hadi Wahyono ${ }^{2}$, Brotosunaryo ${ }^{3}$ \\ 1,2,3,Department of Urban and Regional Planning, Faculty of engineering, Diponegoro University, Indonesia
}

Received: 17 January 2017; Accepted: 5 March 2017; Published: 30 March 2017

\begin{abstract}
This paper aims to understand the role of urbanization in the emergence of in urban area street vendors. In the case of Semarang, more than $54 \%$ of its street vendors come from its hinterlands. These sectors turn to development dichotomy that have a positive and negative impact. Positively, this area becomes people's economic resilience. In the negative side, more than $60 \%$ of vendors make their stall in the public space. This research uses a mix-method approach taking 271 samples, Focus Group Discussion (FGD) and in-depth interview. From this study, it can be concluded that urbanization has led to the outbreak of street vendors through (1) rural-urban migration, and (2) social change as a result of gentrification. Working as street vendors turned out to be an alternative way of life to adapt to global economic uncertainty. Also, there are $71.6 \%$ of street vendors open their stalls in 2003-2009, or about 6-7 years after the monetary crisis (1997). It shows that the financial crisis is not the primary trigger for the outbreak of street vendors. Another interesting finding is that there is a new phenomenon in the form of the intervention of the middle class who took part in this business.
\end{abstract}

\section{Keywords}

characteristics; street vendors; urbanization

\section{INTRODUCTION}

Globalization has led to the rapid growth of cities and further makes cities in the world can not 'stand alone', they become interconnected and influence each other, supported by the rapid flow of information and the development of global economy (Thorns 2002; Ahsan 2011). The conditions that cause between countries, between urban and ruralurban migration (Prajanti \& Hutomo 2016), direct many cities-especially in developing countries-towards uncontrolled urbanization. In fact, there is a tendency that today's urban growth has exceeded projections and inclined towards the shanty town (Thorns 2002). In 2010, Indonesia became one of the nations with the largest urban populations in East Asia and the Pacific region. World Bank (2012) noted $\pm 49.8 \%$ of Indonesian dwells in cities. This number will continue to flourish to nearly $68 \%$ by 2025 and approximately $90 \%$ of the population is likely to live in the towns, especially in Java and Sumatera (World Bank 2009). The concentration of the people in the urban area leads to the transformation of urban industrialization .

Most urbanization occurrs in developing countries, including Southeast Asia,

\section{Corresponding author}

A Building, $3^{\text {th }}$ Floor, Department of Urban and

Regional Planning, Undip Tembalang, Semarang,

50275, Central Java, Indoneis

Email

sariffuddin@pwk.undip.ac.id 
driven by increased investment in the industrial sector (Elias \& Noone 2011; Firman 2002; Rana 2011). This condition leads to the transformation of urban communities, especially in the economic field that previously depends on the agricultural sector changes into sectors of industry and services. This phenomenon is supposed to continue with the rapid process of industrialization in Indonesia (Kemenperin 2010). It is understood that these developments encourage the emergence of informal sector which is a way of urban communities to survive, but the problem is the development of these industries often leads to various problems of the urban environment. In the global context, the growth of the city (sustainable urban growth) becomes a strategic issue that remains debatable to improve the quality of life of urban communities through the improvement of environmental quality. Environmental management addresses to the needs of the present and future generations, further, it is expected that growth of cities can work together with the availability of urban natural resources including urban space. This is partly done through urban development policies and strategies oriented to sustain urban development (Setioko, Pandelaki, \& Murtini 2012; Miguez 2014), by increasing awareness of the development of informal sector that evolved into a necessity in urban scholars.

So far, the primary attention of researchers and urban planning is more concerned on the formal aspects that could be arranged technically appropriate to policy directives such as housing and urban infrastructure; not a lot of special attention is given to the informal sector (Parthasarathy 2009; Aluko 2010) whereas today's informal sector has emerged as a development paradox that is not separated from the process of urban development and evolution. Urban informality has got serious attention from urban scholars since the last two decades. The shift of focus is a necessity like what is stated by Patrick Geddes-Cities in Evolution, written in 1915 telling that urban evolution is the evolution of social conditions which will directly affect the urban space (Geddes 1915; Singh
2011; Tian 2017).

Street vendors as a part of urban informality constitute a new urban growth phenomenon in the third world country such as Indonesia. Street vendors booming is a consequence of urbanization (Roy 2007; Rukmana 2008; Soetomo 2009; Boonstra 2011), a gap of citizen welfare (Falco, Kerr, Rankin, Sandefur, \& Teal 2011; Handoyo \& Widyaningrum 2015) and a new job source for the poor, uneducated and immigrant to the cities (Handoyo 2014; Maneepong \& Walsh 2013). It is considered to be one new way of urban living to survive in the urban growth circumstance (Irianto 2014; Roy \& AlSayyad 2003; Yigitcanlar 2015). Moreover, Roy \& AlSayyad (2003) regard the informal sector as the mode of urbanization through social transformation from agrarian to industrial society.

Regarding the growth of urban population, Semarang is an example of metropolitan cities which is being affected by urbanization from its surrounding areas. According to the Ministry of Public Works as cited in Mulyana, Dodman, Zhang, and Schensul (2013), more than one-third of Kedungsepur's population is likely to settle in the Semarang City, where the annual population growth of the City is $1.4 \%$. Furthermore, in 2030, Semarang's population will reach 7.156 million, and more than $36 \%$ of them lives in the Semarang City.

Urbanization in Semarang city has occurred since the colonization era when the Dutch conducted trading activities in the harbor of Semarang. Not only the urbanization has impacted the social structure of the society, but also the urban land use has simultaneously converted from one to another use (Setioko 2010). Moreover, a recent urban study in Semarang by Wilonoyudho (2010), suggests that according to the analysis of socio-economic aspects, environmental aspects and their implications for urban development, urbanization in Semarang, in some cases, has resulted in the emergence of informal sectors The urbanization in Semarang city is not a consecutive process of transformation from agricultural sectors to industrial sectors and then to service in- 
dustries. However, Wilonoyudho (2010) claimed that there is a direct transformation of agricultural sectors of the urban economy to service industries. Furthermore, the industrialization in the coastal area may not significantly influence the process of urbanization in Semarang City. Economic growth in Semarang city has led to an environmental degradation, congestion, unemployment, crime, social-political conflict and increased informal sector. As an impact, Semarang city suffered an imbalance between population growth and economic growth. It is understood that these conditions will lead to the transformation of space, where the characteristics of urban and rural areas will be blurred (Firman 2002).

According to the phenomenon described above, this article aims to explain the role of urban population growth to street vendors emerging in Semarang City. This paper consists of 4 (four) parts, i.e. (1) the urban population growth in Semarang, (2) the characteristic of street vendors, (3) the nature of informal space, and (4) the role of urban population growth to street vendors emerging.

\section{RESEARCH METHOD}

This paper is based on questionnaire surveys, Focus Group Discussion (FGD), and indepth interview. Quantitative data were obtained from questionnaire surveys of 271 respondents of street vendors (see Table 1). The questionnaires were distributed in 8 sub-districts in the Semarang City including Banyumanik, Tembalang, South Semarang, North Semarang, West Semarang, EastSemarang, Central Semarang and Pedurungan. The surveys were carried out in 2013. Then, the result of the study was updated in 2014 and in 2015 in selected areas by redistributing the questionnaire with a rapid growth of street vendors. This updating process is to accommodate a high rate growth of street vendors in some areas and to provide the most actual data set for the study. After all data being compiled, the descriptive statistical method was employed to analyze the data. To validate the result from question- naire surveys, Focus Group Discussions (see Table 2) have been done with some stakeholders who influence street vendors.

Table 1 Sample of respondent

\begin{tabular}{lrc}
\hline \multicolumn{1}{c}{ Subdistrict } & $\begin{array}{r}\text { Number } \\
\text { of Street } \\
\text { Vendors }\end{array}$ & $\begin{array}{c}\text { Number of } \\
\text { Sample }\end{array}$ \\
\hline Banyumanik & 317 & 16 \\
Pedurungan & 493 & 16 \\
West Semarang & 1.676 & 42 \\
South Semarang & 1.066 & 28 \\
Central Sema- & 2.723 & 71 \\
rang & & \\
East Semarang & 2.075 & 41 \\
North Semarang & 1.509 & 42 \\
Tembalang & 139 & 15 \\
\hline \multicolumn{1}{c}{ TOTAL } & 9.998 & 271 \\
\hline
\end{tabular}

Focus Group Discussion invited street vendors' stakeholders i.e. the government, traders, consultants, urban planners and NGOs. They were invited to discuss and share together issues in each other's. Tabel 2 informs the stakeholders involved in FGDs.

Table 2. Focus Group Discussion member

\begin{tabular}{|c|c|}
\hline Stakeholder & $\begin{array}{c}\text { The role } \\
\text { (information target) }\end{array}$ \\
\hline $\begin{array}{l}\text { The head of } \\
\text { market authority }\end{array}$ & $\begin{array}{l}\text { Trend of street vendors } \\
\text { growth in Semarang }\end{array}$ \\
\hline $\begin{array}{l}\text { Staff of develop- } \\
\text { ment planning } \\
\text { board }\end{array}$ & $\begin{array}{l}\text { Planning and develop- } \\
\text { ment strategy to face } \\
\text { street vendors booming }\end{array}$ \\
\hline $\begin{array}{l}\text { Non-Govern- } \\
\text { mental Organi- } \\
\text { zation }\end{array}$ & The street vendor life \\
\hline $\begin{array}{l}\text { The leader of } \\
\text { street vendors } \\
\text { group }\end{array}$ & $\begin{array}{l}\text { Potency and problem } \\
\text { from street vendors' } \\
\text { perspective. }\end{array}$ \\
\hline $\begin{array}{l}\text { Urban planning } \\
\text { consultants }\end{array}$ & $\begin{array}{l}\text { Street vendor planning } \\
\text { and development }\end{array}$ \\
\hline
\end{tabular}

Based on these references, the researcher obtained variables to identify the role of urbanization in street vendors emerging, which are categorized into 4 objective and variables. Those objectives are (1) describe urban population situation: population growth rate, and informal sector growth rate, (2) describe street vendors characteristic: 
ware, and management, (3) describe informal space aspect: space used to trade, and licensor, (4) infer the role of urbanization in the emergence of street vendors: migration and social change.

The qualitative data were obtained from interviews with several informants who are involved directly with vendors and also FGDs in 2015. The FGDs were attended by representatives of the leader of the street vendors, the market authority of Semarang City (Indonesian: Dinas Pengelola Pasar), Development Planning Board (Indonesian: Bappeda), local NGOs, and town planning consultants. The information gathered from the interviews with stakeholders were used for validation and confirmation of the statistical dataset collected from questionnaire surveys by comparing relevant information obtained from stakeholders to the statistical results. To do so, content analysis was conducted through the repetition of information from each informant (stakeholder). The last source of the data were the literature of previous studies that are primarily development strategies to manage street vendors by local government constituting town master plan, statistical data, and research documents.

\section{RESULTS AND DISCUSSION}

\section{Urban Population Situation}

Semarang is the capital of Central Java Province as well as the core of Kedungsepur's ${ }^{1)}$ National Strategic Area. The total population is 1.55838 million live in around $373.78 \mathrm{~km}^{2}$ (Statistics Indonesia 2012). As the Kedungsepur center, Semarang leads economic growth to surrounding area. As a result, Semarang city becomes a people migration destination. Ministry of Public Works (2012) projects that the population will reach about 7.156 million by 2030 . Population growth rate is $1.4 \%$ per year, higher than the population growth rate of Semarang's hinterland (only $0.7 \%$ ). This phenomenon indicates that Kedungsapur drives the population growth in Semarang.

1 Kedungsepur is an acronym of Kendal-Demak-Ungaran (Semarang District)-Semarang-Purwodadi (Grobogan District). KSN Kedungsepur established through the Government Regulation No. 26 of 2008 on the national spatial plan.
Ministry of Public Work estimates about 36\% of the Kedungsepur's population will live in Semarang by 2030. Furthermore, the rapid increase of population and economy has an adverse effect especially: environmental degradation, congestion, unemployment, crime, social-political conflict and the growing number of the informal sector (Wilonoyudho 2011). In 2009, International Labor Organization (ILO) noted that Indonesian people who work in the informal sector reached $60.2 \%$ (ILO, 2012). Furthermore in 2011, Statistic Indonesia recorded that the number increased to $62.17 \%$ (BPS, 2011). According to Statistic Indonesia's indicators ${ }^{2}$, informal workers in Semarang City increased about 0,12\%) from the previous year $(49,86 \%)$ (Analysis based on Statistics Indonesia 2012).

\section{Characteristic of street vendors}

In 2012, Market Authority of Semarang City records, the number of street vendors is about 9,998 (in eight sub-district) of 11,940 (all street vendors in Semarang City) (Prihadi, 2013), with the following details in Table 3.

Table 3. Number of street vendors in 8 subdistrict

\begin{tabular}{clc}
\hline No. & \multicolumn{1}{c}{ Name of subdistrict } & $\begin{array}{c}\text { Number of } \\
\text { street vendor }\end{array}$ \\
\hline 1. & Pedurungan sub-district & 493 \\
2. & Tembalang sub-district & 139 \\
3. & Banyumanik sub-district & 317 \\
4. & $\begin{array}{l}\text { Central Semarang sub- } \\
\text { district }\end{array}$ & 2.723 \\
5. & $\begin{array}{l}\text { North Semarang sub- } \\
\text { district }\end{array}$ & 1.509 \\
6. & $\begin{array}{l}\text { East Semarang sub- } \\
\text { district }\end{array}$ & 2.075 \\
7. & $\begin{array}{l}\text { South Semarang sub- } \\
\text { district }\end{array}$ & 1.066 \\
8. & West Semarang sub- & 1.676 \\
& district & Total \\
\hline
\end{tabular}
Source: Market Authority of Semarang City, 2012

2 Formal and informal activities of the working population can be identified based on employment status. Of the seven major categories of employment status, formal workers trying to help cover category and the category of workers still labor / employee, the rest including informal workers (Statistics Indonesia, 2011). 
According to the product sold, the street vendors can be categorized into nine categories (see Table 4): food/ culinary, household ware, clothing, automotive accessories, haircut services, other services, electronics, ornamental plants, and other types of street vendors (tire repair shop, etc.). Culinary street vendors are dominant (145 respondents or $\pm 71.59 \%)$. The street vendorsgoccupy public spaces such as parks and highways. Table 3 also shows the percentage of street vendors according to the goods sold.

Table 4. Type of street vendor according to goods selling

\begin{tabular}{llr}
\hline No & Type of street vendor & $\begin{array}{r}\text { Percentage of } \\
\text { street vendors }\end{array}$ \\
\hline 1 & Culinary & $64,94 \%$ \\
2 & Household goods & $7,01 \%$ \\
3 & Clothing & $4,80 \%$ \\
4 & Automotive Acces- & $4,43 \%$ \\
& sories & \\
5 & Haircut service & $3,69 \%$ \\
6 & Other services & $0,04 \%$ \\
7 & Electronic accessories & $2,21 \%$ \\
8 & Ornamental plants & $1,85 \%$ \\
9 & Others & $7,38 \%$ \\
\hline
\end{tabular}

Culinary. Food vendors dominate type of street vendors in the city of Semarang,i.e., more than $64.94 \%$ selling various kinds of food from within Semarang and from surrounding area. The sample can be seen in Figure 1. Based on the food sold, there are at least three variations of time to operate the stall i.e., (1) The stalls that operate during the day, generally at 9:00 to 15:00, (2) stalls opening in the afternoon-evening, usually at 4 p.m. to 22:00, and (3) The stalls that open from noon till night, generally from at 9:00 a.m. to 21:0o. The third variation of this trade show the variety of food sold. Stalls that operate during the day are usually a stall selling snacks such as ice juice, fruit salad, and others. While the stalls that operate in the afternoon-evening in the form of main course such as soup, kethoprak, kupat tahu, and others. The stalls that open during the day (day - night) usually are meatball stall.

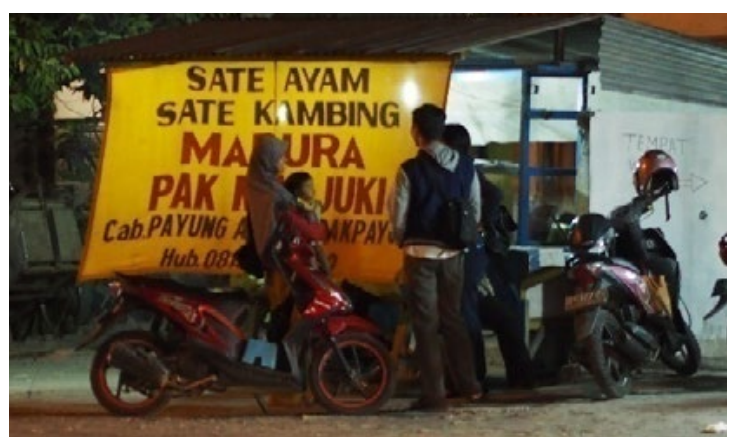

Figure 1. Culinary street vendor in Tembalang

In fact, more than $78 \%$ of street vendors has not been organized and got a trade license from the local district office or from residents whose land is used. Only a small portion of street vendors are in an arranged space as Simpang Lima area and Park of Menteri Supeno (Taman KB). The space used for culinary street vendor is shown in Figure 2.

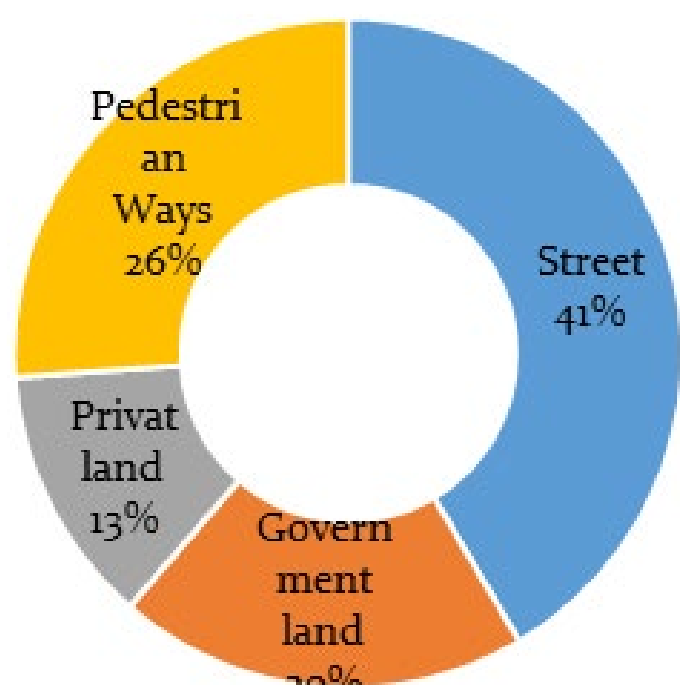

Figure 2. Space used for culinary street vendor

Household goods. Merchants' of household supplies, as much as $7.01 \%$, sell a variety of household items such as pans, pots, and other appliances. Most of sellers ride private vehicles such as motorcycles and cars as places of their shanties. Moreover, they operate from morning to evening with two ways, to put their cars in a single 
location and to sell it around. In general, in the morning (o7:00 to 11:00) they sell in the crowded areas in the center of the settlement ad temporary markets and the early afternoon around the housing.The use of motorized vehicles such as motorcycles and cars became a reason for traders to wider the sales area. Particular types of ware and is not needed in all times, it is the reason for traders to use a motor vehicle to reach more customers.

Clothing. A total of $4.80 \%$ of traders selng clothes, sandals, and various supporters accessorirs. Moreover, the large number (95\%) of street vendors has not been arranged. Thm kind of clothing street vendors: (1) Street vendors by holding ware, these street vendors can be found along the road in the city of Semarang.

Automotive Accessories. Automobile and motorcycle accessorie Sstreet vendors are one of the rare street vendors. Usually they sell cars and motorcycles ware, as well as motorcycle and automobile equipment, such as helmet, etc. Variations of this kinrm of street vendors are (1) Semi-permanen Sstreet vendnt, sell:tTires, wheels and other equipment. The street vendors can be found in Kedung Mundu, Lamper, etc. (2) Street vendory sell helmets, gloves, masks, etc non-permanently. Street vendor of this type can be found in the Taman KBU, Pamularsih and Perintis Kemerdekaan. Haircut servic. Oopeng the semi-permanent stalls in public spaces such as residential drainage, curb or on the edge of the river.

Other services. Some street vendors seng school equipmenresuch as stationery, books, etc. Street vendoredare clustered along the street oy Johar Market, Soccer Stadium, Lamper Lor, and others. One location of street vendorofwhich becomes the icons of Semarang in the area of the stadium. This street vendor is very important for students who need a cheap used books.

Electronic accessories. Street vendors selling various types of electronic equipment and telephone pulses are located in some of the main roads in the city of Semarang. Goods sold include a secondhanded phone, starter packs and pulseisT- he stalls are usually located on the roadside with a semi and non-permanent stalls.

Ornamental plants. Street vendors selling flowers and ornamental plants are only in Pasar Kembang (near RSUP Karyadi) and in Lamper Lor (see Figure 3 ). he an openstall, traders are grouped with semipermanent buildings.

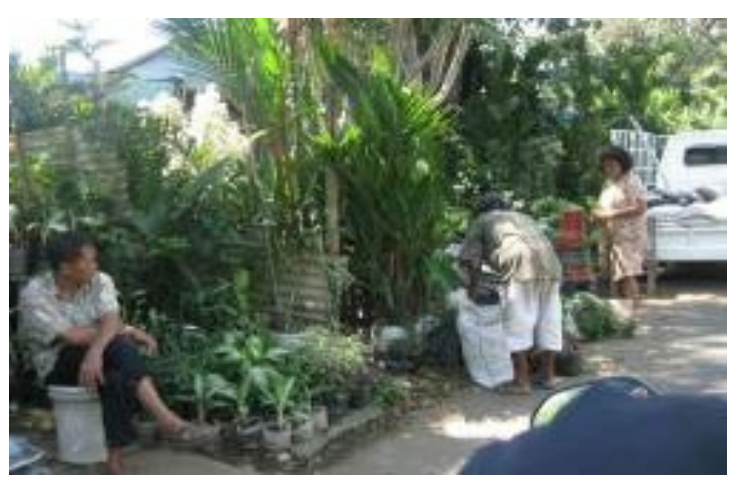

Figure 3. Ornamental plants in Lamper Lor.

Others. This is a street vendor who provides tire repair services, wheel repair, duplicating of vehicle number plates, stamps, clothing, shoes repair duplicatnge keys and others. This is the type of street vendors along the main road and dispersed.

\section{Where Do the Vendors Come From?}

The answer is in their tent. Mostly, the sellers wrote their hometown on the tents. It is associated with typical products offered from their homelands. As an example are Gudeg (from Yogyakarta), Nasi Gandul (from Pati and Kudus), Ketoprak (from West Java), Kupat tahu (from Magelang), Swike (from Grobogan), and so on. They come rushing along family members who then rthe houses to settle temporarily. In general, there are agents that accommodate their work. Theis agences aare pioneer in charge of opening the market and providges ware. This process applies in almost all the traders of food.

Retailer cooperation system among the agencies is very simple and kinship. They mainly involve a revenue sharing system, such as 10: 1, which means if a vendor could sell ten bowls of meatballs then get a bonus of 1 cup for sale. So that the revenue generated by the retailere is very dependent on the amount of ware sold. This system also app- 
lies to the provision of goods infrastructure such as tents, wagons and so oe rRetailers who do not hahe sale equipmele usually get the facilities from agents or their community. The financial system is also applicable as a community gathering to improve the welfare of members. Determination of sales locations is also carried out amicably by the association. They divide the location / sales spes and make the rules together. Each location is set for one vendor, thus another vendor from the same community can not join in the same area. The family system applies hereditary and no administration on a regular basis. They made a simple unregistered 'firm'. They asked permission to sell verbally and sometimes written in the form of contractual use of land, electricity and water to the land owneho that is also facilitated by the association. Thsee patterns of cooperatiis only apply to migrants and do not apply to natives born street vendors and raised in the city of Semarang. This system is also appleds to vendors he other cities in Indonesia.

Native vendor-originally from Semarang-is the result thegentrification process. Residents are not capable of competing with the newcomers ato a make them marginalized. They sell the land in strategic locations becau isthey are not able to utilize iey pref bebeing informal workers such as parking attendants and security in boarding ho. Aas what happened in District Tembalang. Prayoga, Esariti, and Dewi (2013) explained the revitalization, social change, population dynamics and social segregation are factors which increase gentrification. Complementing these studies, they found that community the tends to work in informal sector, for instance as a NasiKucierssellers, unregistered drivers, guards parking ang ice juice vendors.

In the contract, native street vendors have no association or cooperation Tthey work individually without any cooperation wihe other vendors. They only have a relationship coordination to determine the locations of sahen which is usually still on the land around their homes.

The explanations givve sows the role of urbanization on the growth and development of the informal sector especially street vendors. Urbanization pointed out is in the form of migration and native social change. Migration accounted for the proliferation of street vendors is better coordinated through a community-informal society. However urbanization as a result of social change on indigenous people is caused by the process of gentrification.

The numers of individual vendors are higher (53.51\%) than those who invite family members or relatives (46.49\%). The involvement of other peopiedvaries from 2 to 7 people for each stalof The street vendors, who have a branch of the businhey could involve more than ten family members/ relatives. The family members and relatives involved are the primary family member (spouse, child or wife) or their kin. There is no management in the trading business. They rely on subsistence mechanisms to manage the company. Evers and Korff (2002), further, stated that the informal sector is part of the shadow economy thre is dominated by subsistence mechanisms.

The mechanism based on subsistence sense of community, kinship and friendship is believed to be the strength of this sector to survive and will not be distracted by the global economy. This is referred to Dimas (2008), and Bappenas (2003) stating that the informal sector has the enormous economic strength to absorb labor and more resilient to face the global economic disturbance. It reinforces the opinion of Soetomo (2009) that street vendors is not urban and not rural character. The mechanism of their businesses is such as traditional trade in the countryside but, in fact, they thrive in an urban area.

\section{Characteristics of Informal Space}

The street vendors seem to change unintentionally public spaces into commercial areas. They set up non-permanent, semipermanent and permanent stalls. Non-permanent stalls were only built by modifying cars, tricycles or motorcycles. Semi-permanent stalls are usually constructed by a tent completed with the facilities including tab- 
les and chairs. Meanwhile, permanent stalls usually constructed from woven bamboo or wooden planks. The number of street vendor buildings is as follows: (1) Non-permanent building is $\pm 64,58$ (\%), (2) Semi-permanent buildings are $\pm 26,20(\%)$, and (3) permanent buildings are $\pm 9,23(\%)$. Before setting up their stalls, as much as $\pm 68.63 \%$ of traders claimed to have obtained 'permission' from related stakeholders and just as much as $31.37 \%$ are unlicensed. In this case, the licensors are Semarang city government and non-government (see Table 5).

Table 5. Street vendors licensors

\begin{tabular}{clc}
\hline No & \multicolumn{1}{c}{ Licensor } & $\begin{array}{c}\text { Percent- } \\
\text { age of } \\
\text { licenses }\end{array}$ \\
\hline 1 & Urban village office & $66,13 \%$ \\
2 & Market managers agency $\left.^{* a}\right)$ & $10,22 \%$ \\
3 & House owner & $8,60 \%$ \\
4 & Private sector (industry, & $4,30 \%$ \\
& modern shop, etc.) \\
5 & Street vendors community & $3,76 \%$ \\
6 & Neighborhoods & $3,76 \%$ \\
7 & Subdistrict offices \\
\hline Note: & *) official agency authorized to issue \\
permits a) Government agency &
\end{tabular}

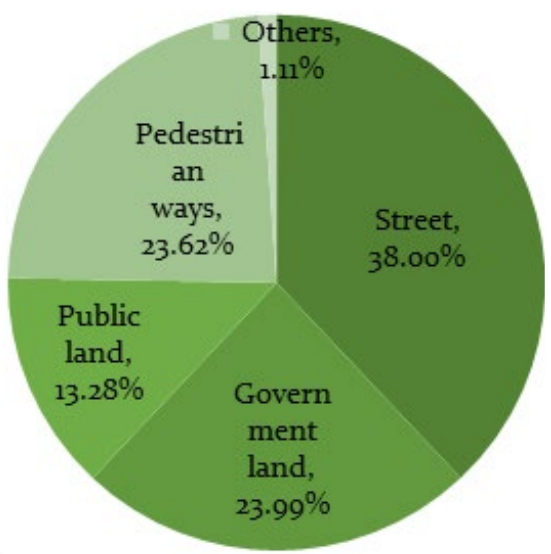

Figure 4. Percentage of informal space

Only $23.99 \%$ of street vendors is accommodated by government land while the permits issued by the government are as much as $79.5 \%$ of all grants that have been published (see Figure 4). As much as $61.62 \%$ of the public space (sidewalks and main road) has transformed from open space into commercial space. This condition would be weird. There is an impression that the city government legalizes the street vendors through licensing by the 'state' (79.5\%). As a reward, they pay a fee of Rp. 5.00o,- up to Rp. $50.000,-$ per month to the license issuer.

The phenomenon described explains the increase of street vendors in the city of Semarang that had 'displaced' public space that should belong to the publicowith 'commercial areas. Roy and AlSayyad (2003) stated that the informal sector is an effort towards a city that does not depend on agricultural sector. It turned out to have an impact on temporary land use (temporary space) and changes over time. In a single day, a single location occupied by street vendors may change the activitiey in it 2-3 times. As an illustration, in Tirtoagung park (Tembalang), in the morning it is occupied by porridge seller and chicken soup, in the day it is used for ice and in the evening, it is uses for martabak seller. This indicates a multifunctional space that runs informal and dynamic activities.

Space functions for various activities carried out by different people. Within the scope of spatial planning, a formal, multifunction space has not been accommodated. A valuable lesson can be obtained from the use of space informally by the street vendors; furthermore it contributes to a formal spatial planning study. Moreover, Roy and AlSayyad (2003) figured out that the informal sector is the mode of urbanization, it may be accommodated in the spaces provided in the multifunctional urban land. This location can refer to the primary sector that clung to the informal sector. It goes deeper from the Evers and Korff (2002) statemen, that the informal sector can also be called underground economy or economic shadow, and then this sector will always follow the core activity of the city.eOne of the many street vendors in the area of Tembalang, is a street vendor who supports scholar activities in this zone where many students need eating, tire services, and so on.

From the legal point of view, the facl found in field observation shows that the characteristic of space usd is an urban management paradox. Many attempts have 
been made by the government to restructure, reduce or displace the street vendors. However, on the other sides they get 'facility' from the government to open their stalls. From the utilization of these illegay spacest we can take a precious lesson thats multi-functional space can be organized and used collectiveld. These findings serve as an input for strengthening public policy for street vendors.

\section{The Role of Urban Population Growth in Street Vendors Emerging}

The emergence of street vendors in Semarang city cannot be separated from the influence of the Semarang metropolitan area (Kedungsepur). Many job-seekers who come to Semarang hope to improve their quality of life. More than $90 \%$ of respondents felt that their work as street vendors remains more profitable than working in villages (farming and livestock). This is a new way of life for the residents of urban communities. They fled the vital sectors (agriculture and livestock) to the service sector or downright non-vital sector (e.g., Parking service, etc.).

The Relationship of up-down town is hugely influential, especially due to the little employment in rural areas and the assumption that Semarang has greater job opportunities. The growth of the informal sector which is higher (1.47\%) than population growth $(1.36 \%)$ indicates that the urbanization that occurred in the city of Semarang more towards informal. This conditiong reinforces the research that has been done by Wilonoyudho (2011) and becomes one of the reasons for the low contribution to the increase in per capita income of urban community that is less than $2 \%$ (World Bank, 2012).

Also, social transformations that occur in indigenous communities contribute to the high number of informal workers, especially street vendors. Research by Prayoga et al. (2013) in the Tembalang sub-district concluded that gentrification has changed the economic condition of the community (65\%). They took advantage of the magnitude of the dynamics of population growth and economic growth of the city by providing informal services'esuch as parking attendant, tire repairman and so on. Some respondents who ar' hawkers there decide to trade (mainly sel- ling angkringan's food 3 ). They choose to rent out stalls they owned and become street vendorSso they get double income. Moreover, they get the impacts of the modernization of urban life ,that is, increased revenue and wider employment opportunities.

Most of the street vendors began their business around ten years ago $(71,59 \%)$ and about $28.41 \%$ of street vendors have been operating for more than 15 years. They have been in the 'comfort zone' and tend not to attempt to change to the formal sector. Their primary consideration is the high cost of rental shops. For more detail, they only use a tent and pay a monthly levy to the village government; they've been able to get a steady income every month. Also, they are more independent and autonomous in setting up financial management of their business. Those are the reasons that make the street vendors persist and tend not to be transformed into the formal legal sector. They continue in the system of taxfree underground economy and the official licensing from the government. The figure of street vendors are basically as the result of marginalized city modernization, like the idea of the formal economy Soetomo (2009) does not apply to all types of street vendors. Recently, some street vendors emerge from the gentrification process.

From this description, urbanization contributor in Semarang city can be predicted. Urbanization and modernization have led to the proliferation of street vendors in Semarang city. Furthermore, Soetomo (2009) argued that the street vendors is a product of urban modernization and ruralurban linkage. The street vendors are not rural and urban. This sector is the result of the selection process of modernization in the city which then attracts migrants from the surrounding area. Semarang metropolitan area or also commonly known as Kedungsapur contributes to the emerging of street vendors in Semarang City. Industrialization in Semarang coastal area becomes one of migration attractions that occurred from the 1980 os to the present (Sariffuddin \& Susanti 2011).

3 Angkringan's food also known as sego kucing/nasikucing and often translated cat rice or cat>s rice is an Indonesian rice dishthat originated from Yogyakarta, Semarang, and Surakarta. It consists of a small portion of rice with toppings, usually sambal, dried fish, and tempeh, wra pped in banana leaves (Wikipedia, 2014) 
One interesting phenomenon found in the field is an emerging middle-class people who work as street vendors. Ware group is more innovative than conventional street vendors; they have sales and clear brand management quality. Most of them sell food, such as fried tofu (for example Kuck-Kuch HoaTahu, Turkish Kebab, Chicken Meal, Cappuccino Cincau, etc.). Many of their stalls found in Tembalang sub-district. The owner or the seller are usually highly educated people and sometimes even university students. Most of them regard this bussiness as 'bridge' to achieve a higher established career.

Transformation of vendors also occurs on the equipment used for trade. Ten years ago, there were still many traders who use carts, bicycles, and stalls pairs. However, the current trade media is starting to switch from manual to motorized mobilesvehicles. Traders preferybuying a motorcycle and a car compared to renting or buying a kiosk for trade.

\section{CONCLUSION}

There are several conclusions that canbe drawn from the discussion. First, the growth of informal sectors in Semarang (1.47\%) is higher than the growth of the city population (1.36\%). It shows that the urbanization in Semarang has resulted in the emergence of informal sectors thn so-called "hypergrowth". The primary cause of this phenomenon is tha community effort to improve the standards of living. Working as street vendors is the way of life to get a better quality of life. This phenomenon is also influenced by the government policy as the authority that "allow" their stalls in public spaces. Second, avillage-urban relationship has exceptionally strong influence especially of Kedungsepur on Semarang. This study shows that the role of government in the management of street vendors is unusually large. Third, a multifunctional space to accommodate street vendors can beea temporary space and considered in urban spatial planning. From this study, there is a suspicion arises that the proliferation of street vendors is due to the high economic subsistence and cultural influence (mainly Javanese culture). Therefore, there is a need for further research which tries to identify more the economiy living and cultural influences in the urban informal sectoe.

\section{REFERENCES}

Ahsan, R., Karuppannan, S., \& Kellett, J., 2011. Climate migration and urban planning system: a study of Bangladesh. Environmental Justice, 4(3), pp. 163-170.

Aluko, O. E., 2010. The Impact of Urbanization on Housing Development: The Lagos Experience, Nigeria. Ethiopian journal of environmental studies and management, pp. 3(3).

Bappenas. 2003. Studi profil pekerja di sektor informal dan arah kebijakan ke depan. Direktorat Ketenagakerjaan dan Analisis Ekonomi, Jakarta.

Boonstra, B., \& Boelens, L., 2011. Self-organization in urban development: towards a new perspective on spatial planning. Urban Research $\mathcal{E}$ Practice, 4(2), pp. 99-122.

BPS. 2011. Berita Resmi Statistik. Badan Pusat Statistik, Jakarta.

Dimas, H., 2008. Street Vendors: urban problem and economic potential. Retrieved from Bandung.

Elias, S., \& Noone, C., 2011. The growth and development of the Indonesian economy.

Evers, H. D., \& Korff, R., 2002. Urbanisme di Asia Tenggara: Makna dan kekuasaan dalam ruangruang sosial (Zulfahmi, Trans.). Yayasan Obor Indonesia, Jakarta.

Falco, P., et al. 2011. The returns to formality and informality in urban Africa. Labour Economics, 18, Supplement 1(o), pp. S23-S31. doi:http://dx.doi. org/10.1016/j.labeco.2011.09.002

Firman, T., 2002. Urban Development in Indonesia, 1990 - 2001: from the boom to the early reform era through the crisis. Habitat International, 26, pp. $229-249$.

Geddes, P., 1915. Cities in evolution: An introduction to the town planning movement and to the study of civics .

Handoyo, E., \& Widyaningrum, N. R., 2015. Relocation as Empowerment: Response, Welfare, and Life Quality of Street Vendors After Relocation. Komunitas: International Journal of Indonesian Society and Culture, 7(1), pp. 30-42. doi:10.15294/komunitas.v7i1.3428

Handoyo, E., 2014. Kontribusi Modal Sosial Dalam Meningkatkan Kesejahteraan Pedagang Kaki Lima Pascarelokasi. Komunitas: International Journal of Indonesian Society and Culture, 5(2), pp. 252-266. doi:http://dx.doi.org/10.15294/ komunitas.v5i2.2743

ILO. 2012. Statistical update on employment in the informal economy. Retrieved from http://laborsta.ilo.org/informal_economy_E.html.

Irianto, A. M., 2014. Strategi Adaptasi PKL Kota Semarang: Kajian Tentang Tindakan Sosial. Komunitas: International Journal of Indonesian Society and Culture, 6(1), pp. 70-90. doi:http:// dx.doi.org/10.15294/komunitas.v6i1.2938

Kemenperin. 2010. Pertumbuhan industri melampaui target (laporan utama). Media Industri, 3. 
Maneepong, C., \& Walsh, J. C., 2013. A new generation of Bangkok Street vendors: Economic crisis as opportunity and threat. Cities, 34, pp. 37-43.

Miguez, M. G., Rezende, O. M., \& Veról, A. P., 2014. City growth and urban drainage alternatives: Sustainability challenge. Journal of Urban Planning and Development, 141(3), pp. 40104026.

Ministry of Public Works. 2012. Draft Technical Report on Semarang Metropolitan Area (Kedungsepur). Ministry of Public Works, Jakarta.

Mulyana, W., et al., 2013. Urbanisation, Demographics and Adaptation to Climate Change in Semarang, Indonesia. Retrieved from Jakarta: http://pubs.iied.org/10632IIED.html

Parthasarathy, D., 2009. Rethinking urban informality global flows and the time-spaces of religion and politic. International Conference on Urban Aspirations in Global Cities.

Prajanti, S. D. W., \& Hutomo, B. S., 2016. Workers' Commuting Migration from District to City of Semarang by Rapid Transit Busses. Komunitas: International Journal of Indonesian Society and Culture, 8(1), pp. 32-38. doi:http://dx.doi. org/10.15294/komunitas.v8i1.4507

Prayoga, I.N.T., Esariti, L., \& Dewi, D.I.K., 2013. TheIdentification of Early Gentrification in Tembalang Area, Semarang, Indonesia. Environment and Urbanization Asia, 4(1), pp. 57-71. doi:http:// dx.doi.org/10.1177/1103308813478606

Prihadi, H., 2013. Sambutan walikota pada acara apel akbar dan pencanangan gerakan nasional hak pedagang kaki lima (GNH-PKL) se-Sawa Tengah. Retrieved from http://www.semarangkota.go.id/portal/index.php/article/ details/-apel-akbar-dan-pencanangan-gerakan-nasional-hak-pedagang-kaki-lima-gnhpkl-se-jawa-tengah-

Rana, M. M. P. 2011. Urbanization and sustainability: challenges and strategies for sustainable urban development in Bangladesh. Environment, Development and Sustainability, 13(1), pp. 237256.

Roy, A., \& AlSayyad, N., 2003. Urban informality: transnational perspectives from the Middle East, Latin America, and South Asia. Lexington Books, New York.

Roy, A., 2007. Urban informality: toward an epistemology of planning. Journal of American Planning Association, 71(2), pp. 147-158. doi:http:// dx.doi.org/10.108o/01944360508976689

Rukmana, D., 20o8. Pedagang kaki lima dan informalitas perkotaan. Retrieved from http://www.jakartabutuhrevolusibudaya.com/2008/04/03/ pedagang-kakilima-dan-informalitasperkotaan/

Sariffuddin, S., \& Susanti, R., 2011. Penilaian kesejahte-raan masyarakat untuk mendukung permukiman berkelanjutan di Kelurahan Terboyo Wetan, Semarang. Makara seri sosial humaniora, 15(1), pp. 29-42.

Setioko, B., 2010. The methamorphosis of a coastal city (case study Semarang Metropolitan). Journal of Coastal Development, 13(3), pp. 148-159.

Setioko, B., Pandelaki, E.E., \& Murtini, T.W., 2012. Towards sustainable urban growth: The unaffected fisherman settlement setting (with case study Semarang coastal area). The 3rd International Conference on Sustainable Future for Human Security, 17, pp. 401-407.

Singh, R. P., Tyagi, V. V., Allen, T., Ibrahim, M. H., \& Kothari, R., 2011. An overview for exploring the possibilities of energy generation from municipal solid waste (MSW) in Indian scenario. Renewable and Sustainable Energy Reviews, 15(9), pp. 4797-4808.

Slettebak, R. T. 2012. Don't blame the weather! Climate-related natural disasters and civil conflict. Journal of Peace Research, 49(1), pp. 163176.

Soetomo, S., 2009. Urbanisasi $\mathcal{E}$ morfologi: proses perkembangan peradaban dan wadahnya menuju ruang yang manusiawi - edisi 2. Graha Ilmu, Yogyakarta.

Statistics Indonesia. 2012. Semarang Municipality in FIgures 2012. Retrieved from Semarang: http:// bappeda.semarangkota.go.id/v2/wp-content/ uploads/2013/10/zSDA2012.pdf

Thorns, D. C., 2002. The transformation of cities: urban theory and urban life.

Tian, L., Ge, B., \& Li, Y., 2017. Impacts of state-led and bottom-up urbanization on land use change in the peri-urban areas of Shanghai: Planned growth or uncontrolled sprawl?. Cities, 6o, pp. 476-486.

Wikipedia.org. 2014. Nasi kucing. Retrieved from http://en.wikipedia.org/wiki/Nasi_kucing

Wilonoyudho, S., 2010. The urbanization in Semarang City. Indonesian Journal of Geography, 42(2), pp. 181-194.

Wilonoyudho, S., 2011. Overurbanization in Semarang City (abstract). Jurnal Teknik Sipil dan Perencanaan, 13(2).

World Bank. 2012. The Rise of Metropolitan Regions: Towards Inclusive and Sustainable Regional Development. The World Bank Group, [online] Available at: http://www.worldbank.org/en/ news/feature/2012/o8/13/towards-inclusiveand-sustainable-regional-development.

World Bank. 2009. World Development Report. World Bank.

Yigitcanlar, T., \& Teriman, S., 2015. Rethinking sustainable urban development: towards an integrated planning and development process. International Journal of Environmental Science and Technology, 12(1), pp. 341-352. 